Krzysztof Królczyk

(Poznań)

https://orcid.org/0000-0002-0923-0940

\title{
PRÓBA UTWORZENIA KATEDRY HISTORII BIZANCJUM NA UNIWERSYTECIE JANA KAZIMIERZA WE LWOWIE. PRZYCZYNEK DO DZIEJÓW BIZANTYNISTYKI W POLSCE ${ }^{1}$
}

\begin{abstract}
This text is concerned with the attempts made in late 1933 to establish Poland's first chair of history of Byzantium at the Jan Kazimierz University in Lwów; utlimately the endeavours proved unsuccessful.

\section{Keywords}

Lwów/Lviv, university, Jan Kazimierz University, Byzantium, Kazimierz Zakrzewski

Jest dziś sprawą powszechnie znaną, że pierwsza polska katedra historii Bizancjum została powołana do życia w 1935 r. na Uniwersytecie Józefa Piłsudskiego w Warszawie 2 . Objął ją doc. Kazimierz Zakrzewski (1900-1941) - świetnie zapowiadający się młody uczony, dotychczas związany z lwowskim Uniwersytetem Jana

${ }^{1}$ Niniejszy tekst jest znacznie rozszerzoną i uzupełnioną wersją artykułu, który ukazał się w 2019 r. w języku niemieckim w księdze pamiątkowej profesora Macieja Salamona (por. Królczyk 2019).

${ }^{2}$ Sprawozdania z działalności Uniwersytetu Józefa Piłsudskiego w Warszawie za rok akademicki 1934-35 i za rok akademicki 1935-36, Warszawa 1936, s. 31; zob. także Rutkowski 2015, s. 120.
\end{abstract}


Kazimierza (ryc. 1)3. Mało kto jednak wie, że zanim warszawska katedra ostatecznie powstała, czynione były starania o utworzenie uniwersyteckiego centrum badań nad dziejami Bizancjum w innym ośrodku akademickim w ówczesnej Polsce, mianowicie we Lwowie. Niestety nie zakończyły się one sukcesem i z tego też powodu pamięć o tej niewątpliwie ciekawej inicjatywie stopniowo zanikała. Zjawisko to nasiliło się zwłaszcza po roku 1945, tj. po utracie Lwowa przez Polskę w wyniku II wojny światowej i pozostawieniu uniwersyteckiego archiwum poza nowymi granicami naszego kraju. Wydaje się jednak, że i dziś jeszcze warto przypomnieć podjętą wówczas przez lwowskich uczonych próbę stworzenia nad Pełtwią polskiego ośrodka bizantynologicznego, stanowi ona bowiem niezwykle interesujący przyczynek do historii badań nad Bizancjum na ziemiach polskich.

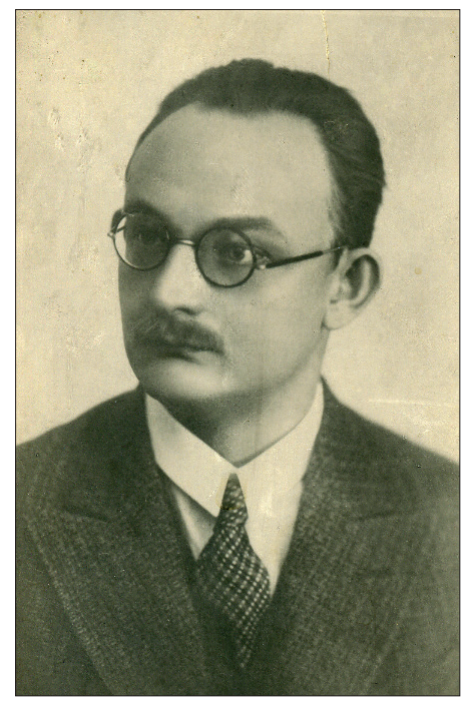

Ryc. 1. Kazimierz Zakrzewski, proponowany kandydat na profesora katedry historii i kultury Bizancjum UJK Źródło: Zakład Historii Bizancjum Uniwersytetu Łódzkiego.

Przedwojenny Lwów był jednym z najsilniejszych ośrodków akademickich w ówczesnej Polsce . Zarazem był też pulsującym i prężnym centrum polskich badań nad starożytnością, od dziejów starożytnego Bliskiego Wschodu poczynając, a na historii późnego antyku kończąc. Zarówno w okresie autonomii galicyjskiej, jak i w okresie międzywojennym działali tu wybitni polscy uczeni reprezentują-

${ }^{3} \mathrm{Na}$ temat postaci Kazimierza Zakrzewskiego zob. Królczyk 2014c, jak również opracowania zawarte w: Dąbrowska (red.) 2015 (tu zwłaszcza teksty M.N. Pawlaka, M. Kozłowskiego, J. Prostko-Prostyńskiego, M. Salamona, T.P. Rutkowskiego).

${ }^{4}$ Dla badań nad dziejami Uniwersytetu Lwowskiego pozostaje nadal niezwykle ważna, oparta na bogatym materiale źródłowym, następująca publikacja: Finkel i Starzyński 1894; najnowsze opracowanie poświęcone lwowskiej Alma Mater: Redzik (red.) 2017. 
cy historię starożytną, filologię klasyczną, historię sztuki antycznej, archeologię (klasyczną i pradziejową, a także biblijną), asyriologię, papirologię oraz prawo rzymskie ${ }^{5}$. Wśród dyscyplin naukowych uprawianych na Uniwersytecie Lwowskim (od 1919 r. noszącym oficjalnie nazwę Uniwersytet Jana Kazimierza we Lwowie) brakowało jednak bizantynistyki, i to pomimo faktu, że przed 1918 r. pewne związki z lwowską Alma Mater mieli dwaj uczeni, którzy wnieśli znaczący wkład w rozwój polskich badań nad dziejami Bizancjum. Mowa tu o Leonie Sternbachu (1864-1940) ${ }^{6}$, który słusznie jest uważany za twórcę polskiej bizantynologii ${ }^{7}$, oraz o filologu klasycznym i bizantynologu Janie Sajdaku (1882-1967) ${ }^{8}$. Pierwszy z wymienionych, po studiach w Lipsku, Dreźnie i Wiedniu, w 1889 r. habilitował się właśnie na Uniwersytecie Lwowskim. Z kolei Jan Sajdak przez krótki czas był profesorem filologii klasycznej na tym samym uniwersytecie (w latach 1916-1919). Nie można wszak skonstatować, by pozostali badacze związani z Universitas Leopoliensis w jakiś szczególnie aktywny sposób włączali się w rozwój polskich badań bizantynistycznych ${ }^{9}$.

Sytuacja ta miała się zmienić dopiero po odzyskaniu przez Polskę niepodległości. Oto w pierwszej połowie lat 20. XX wieku na Uniwersytecie Jana Kazimierza we Lwowie pojawił się młody badacz, który z biegiem czasu zaczął wykazywać coraz większe zainteresowanie dziejami późnego antyku i Bizancjum. Był nim wspomniany na początku naszych rozważań Kazimierz Zakrzewski. Podczas studiów uniwersyteckich we Lwowie ${ }^{10}$ trafił on, w roku akademickim 1922/23, na semina-

${ }^{5}$ Zob. Królczyk 2007; idem 2015; idem 2016. Wspomnieć należy w tym miejscu, że do grona uczonych zajmujących się starożytnością na UJK należeli wówczas, obok Polaków, także badacze narodowości ukraińskiej, jak archeologowie Iwan (Jan) Starczuk (1894-1950) i Markian (Marcjan) Orest Smiszko (1900-1981). Pierwszy był adiunktem przy katedrze archeologii klasycznej UJK, natomiast drugi - adiunktem przy katedrze prehistorii UJK. O ich działalności w międzywojennym Lwowie pisze m.in. Oleksandr Sytnyk (Sytnyk 2012, s. 103-106 i 138-145).

${ }^{6} \mathrm{Na}$ temat postaci wielkiego polskiego filologa i bizantynisty Leona Sternbacha zob. m.in. Korus 2004-2005.

7 Por. Ceran 2005, s. 8.

8 Jan Sajdak studiował filologię klasyczną na Uniwersytecie Jagiellońskim. Przez krótki czas był docentem prywatnym na UJ (od 1912 r.), następnie profesorem latynistyki na Uniwersytecie Lwowskim (od 1916 r.), natomiast od 1919 r. aż do przejścia na emeryturę - Uniwersytetu Poznańskiego (od 1955 r. - Uniwersytetu im. A. Mickiewicza w Poznaniu). Jego sylwetkę przybliża, jak dotąd najpełniej, Ignacy Lewandowski (Lewandowski 2009).

9 Warto jednak w tym miejscu odnotować, że po śmierci wybitnego bizantynisty Karla Krumbachera (na jego temat zob niżej, przyp. 46), która nastąpiła w 1909 r., część jego prac naukowych (oraz - być może - prywatne archiwum) została zakupiona przez metropolitę lwowskiego obrządku wschodniego Andrzeja Szeptyckiego (1866-1944) i trafiła do Lwowa do zorganizowanego przez arcybiskupa ukraińskiego muzeum sztuki „Studion”; dziś prace K. Krumbachera z tej kolekcji znajdują się w zbiorach Biblioteki Uniwersyteckiej we Lwowie. Szerzej na ten temat: Kryvenko i Fayda 2013.

${ }^{10}$ Ich przebieg dokumentuje indeks K. Zakrzewskiego („książeczka legitymacyjna”), zachowany w zbiorach Archiwum Nauki PAU i PAN w Krakowie (sygn. K III - 206). 
rium prowadzone przez profesora Konstantego Chylińskiego (1881-1939), wybitnego znawcę czasów starożytnych ${ }^{11}$. W listopadzie 1923 roku Zakrzewski uzyskał doktorat na podstawie przedłożonej rozprawy historycznej poświęconej miastom rzymskiej prowincji Achaja ${ }^{12}$. Praca ta, ogłoszona drukiem dwa lata później ${ }^{13}$, prezentowała wewnętrzne dzieje poleis południowego Peloponezu w okresie od $196 \mathrm{r}$. przed Chr. do początków V w. po Chr., tj. do najazdu Alaryka. Już wówczas młody uczony dał wyraz swoim zainteresowaniom historią późnoantyczną.

Po zatwierdzeniu doktoratu Kazimierz Zakrzewski został zatrudniony na Uniwersytecie Jana Kazimierza przy kierowanej przez Konstantego Chylińskiego katedrze historii starożytnej: zrazu jako asystent młodszy (od 1 kwietnia 1925 r.) ${ }^{14}$, a następnie, od 1 kwietnia 1927 r., jako asystent starszy ${ }^{15}$. Na rok akademicki 1925/26 otrzymał od rządu francuskiego dziesięciomiesięczne stypendium do Paryża ${ }^{16}$, gdzie miał możliwość pracować pod kierunkiem tamtejszych wybitnych uczonych, w tym zwłaszcza Gabriela Milleta ${ }^{17}$ i Pierre’a Jougueta (1869-1949) ${ }^{18}$. Ten ostatni w liście do Jana Ptaśnika (1876-1930) ${ }^{19}$, dziekana Wydziału Filozoficznego UJK, mocno chwalił czynione przez polskiego uczonego postępy ${ }^{20}$. W Paryżu przygotowywał też Zakrzewski swoją rozprawą habilitacyjną, która miała być poświęcona epoce późnego Cesarstwa, coraz bardziej zajmującej polskiego badacza. Książka, traktująca o rządach wschodniorzymskiego cesarza Arkadiusza (panował w latach 395-408), ukazała się w 1927 r., już po powrocie K. Zakrzewskiego do Pol$\mathrm{ski}^{21}$. Na jej podstawie, po przeprowadzonym kolokwium habilitacyjnym (7 grud-

11 O Konstantym Chylińskim zob. ostatnio: Pisulińska 2007; Królczyk 2014a; Królczyk $2014 b$.

12 Oryginał dysertacji K. Zakrzewskiego przechowywany jest w Państwowym Archiwum Obwodu Lwowskiego we Lwowie (Derżawnyj Archiw Lwiwśkoji Oblasti, dalej cyt. DALO), f(ond) 26, op(is) 4, spr(awa) 265; oceny doktoratu podjęli się Konstanty Chyliński (DALO, f. 26, op. 15, spr. 728 [protokoły egzaminów doktorskich 1916-1924], ark. 339-339 verso) i Stanisław Witkowski (DALO, f. 26, op. 15, spr. 728, ark. 340); egzamin doktorski Kazimierz Zakrzewski zdał z wynikiem celującym (DALO, f. 26, op. 15, spr. 728, ark. 341).

13 Zakrzewski 1925a.

14 DALO, f. 26, op. 5, spr. 713 (teczka osobowa K. Zakrzewskiego), ark. 4.

15 Ibidem, ark. 22.

16 Ibidem, ark. 12.

17 Gabriel Millet (1867-1953) - francuski bizantynolog, profesor Collège de France, prowadził m.in. badania na górze Athos; zob. Jolivet-Lévy (2020).

18 Pierre Jouguet - francuski filolog klasyczny i egiptolog, w latach 1920-1933 profesor paryskiej Sorbony, długoletni dyrektor Institut Français d’Archéologie Orientale (1928-1940); dzięki jego pomocy zainicjowane zostały polskie badania archeologiczne w Egipcie (w Edfu). Szerzej na jego temat zob. Manteuffel 1949.

19 Jan Ptaśnik był mediewistą, profesorem historii na Uniwersytecie Jana Kazimierza we Lwowie. Por. Bieńkowski 1986.

20 DALO, f. 26, op. 5, spr. 713 (teczka osobowa K. Zakrzewskiego), ark. 13-14.

21 Zakrzewski 1927. 
nia 1925 r.) 22 i wykładzie „Państwo mykeńskie i Achajowie w Pamfilji” (15 grudnia 1925 r. $)^{23}$, postanowieniem Rady Wydziału Humanistycznego UJK z dnia 15 grudnia 1927 r., Kazimierz Zakrzewski uzyskał habilitację w zakresie historii starożytnej z uwzględnieniem dziejów wczesnego Bizancjum ${ }^{24}$. Decyzja Rady została zatwierdzona przez Ministerstwo Wyznań Religijnych i Oświecenia Publicznego, o czym Zakrzewskiego poinformowano pismem z dnia 9 lutego 1928 r. ${ }^{25}$

Prawie równocześnie Kazimierz Zakrzewski wystąpił do Rady Wydziału Humanistycznego UJK o udzielenie mu urlopu na trzeci trymestr roku akademickiego 1927/28. Było to związane z jego planami życiowymi. Uczony pragnął bowiem przenieść się z Lwowa do Poznania, by tam objąć wakującą katedrę historii starożytnej na Uniwersytecie Poznańskim ${ }^{26}$. Zgodę Rady uzyskał; została ona udzielona jednomyślną decyzją w dnia 28 kwietnia 1928 r., a następnie zatwierdzona przez ministerstwo w Warszawie ${ }^{27}$.

Kazimierz Zakrzewski rzeczywiście przyjechał do Poznania i podjął wykłady z historii starożytnej na Alma Mater Posnaniensis, w „profesorskim wymiarze godzin”28, niemniej katedry historii starożytnej na Uniwersytecie Poznańskim ostatecznie nie objął. Wydział Humanistyczny UP, z nieznanych dziś bliżej powodów, odrzucił bowiem prośbę K. Zakrzewskiego o przeniesienie „prawa do wykładania” (venia legendi) do Poznania ${ }^{29}$. W związku z tym uczony zdecydował się wrócić do Lwowa, co też nastąpiło pod koniec 1928 r. Dnia 22 grudnia 1928 r. Kazimierz Zakrzewski oficjalnie powiadomił Radę Wydziału Humanistycznego UJK o swoim powrocie, wyrażając jednocześnie wolę podjęcia w drugim i trzecim trymestrze wykładów ${ }^{30}$. W dniu 18 stycznia 1929 r. złożył wniosek o zatrudnienie go w charakterze starszego asystenta przy katedrze archeologii klasycznej UJK, kierowanej

${ }^{22}$ DALO, f. 26, op. 5, spr. 713 (teczka osobowa K. Zakrzewskiego), ark. 32-34.

${ }^{23}$ Ibidem, ark. 28.

${ }^{24}$ Ibidem, ark. 44.

${ }^{25}$ Ibidem, ark. 55.

${ }^{26}$ Katedra ta, powstała w 1919 r. jako pierwsza w Polsce, od czasu wyjazdu w 1922 r. profesora Ludwika Piotrowicza (1886-1957; na jego temat zob. m.in. Sprawski 2018) z Poznania do Krakowa pozostawała nieobsadzona, a całość dydaktyki z historii antycznej na Uniwersytecie Poznańskim była prowadzona przez profesorów filologii klasycznej (Mrozewicz 2011, s. 17).

${ }_{27}$ DALO, f. 26, op. 5, spr. 713 (teczka osobowa K. Zakrzewskiego), ark. 52-53.

${ }^{28}$ Uniwersytet Poznański. Spis wykładów na 1, 2, 3 trymestr roku akademickiego 1928/29, Poznań 1928, s. 51. Zob. także Archiwum Akt Nowych, zespół Ministerstwa Wyznań Religijnych i Oświecenia Publicznego, sygn. 6765, k. 23. Informację tę potwierdzają wpisy z lat akademickich 1927/28 i 1928/29 dokonane przez Kazimierza Zakrzewskiego do indeksu jednego ze studentów Wydziału Humanistycznego UP (w posiadaniu autora niniejszego tekstu).

${ }^{29}$ DALO, f. 26, op. 5, spr. 2016 (teczka osobowa K. Chylińskiego), ark. 135.

${ }^{30}$ DALO, f. 26, op. 5, spr. 713 (teczka osobowa K. Zakrzewskiego), ark. 57. 
przez profesora Edmunda Bulandę (1882-1951) $)^{31}$, który następnie został pozytywnie rozpatrzony przez radę wydziałową i senat uczelni ${ }^{32}$.

Choć po powrocie do Lwowa Kazimierz Zakrzewski intensywnie pracował naukowo i publikował liczne prace, głównie z zakresu historii późnego Rzymu i Bizancjum ${ }^{33}$, prowadził regularne wykłady uniwersyteckie $\mathrm{z}$ tej właśnie tematy$\mathrm{ki}^{34}$, jak również ćwiczenia $\mathrm{z}$ historii antycznej ${ }^{35}$, to przecież zatrudnienie docenta $\mathrm{z}$ habilitacją $\mathrm{w}$ charakterze asystenta (a od pewnego czasu jako asystenta woluntariusza, tzn. niepobierającego regularnego wynagrodzenia ${ }^{36}$ ), $w$ dodatku przy katedrze archeologicznej, nie było najszczęśliwszym rozwiązaniem ani dla uczelni (niemogącej w pełni wykorzystać potencjału naukowego badacza), ani dla samego zainteresowanego. W związku z powyższym profesor Konstanty Chyliński, mistrz uniwersytecki K. Zakrzewskiego, oraz profesor Edmund Bulanda (ryc. 2), ówczesny bezpośredni przełożony uczonego, postanowili znaleźć inne rozwiązanie w tej dość złożonej i trudnej dla wszystkich sytuacji.

Oto na posiedzeniu Rady Wydziału Humanistycznego UJK w dniu 15 listopada 1933 r. obaj profesorowie poinformowali zebranych, że pragną zaproponować utworzenie na lwowskiej uczelni katedry historii i kultury Bizancjum, gdyż pojawił się doskonały kandydat do jej objęcia w osobie dr. Kazimierza Zakrzewskiego. Obaj uczeni podkreślili, że w przedmiotowej sprawie przygotują odpowiedni memoriał na następne posiedzenie Rady, proponując zarazem wybór komisji do wyboru odpowiedniego kandydata (był taki formalny wymóg). Mieli do niej wejść członkowie Komisji Historycznej (wchodzili w jej skład profesorowie historii zatrudnieni

${ }^{31}$ Edmund Bulanda studiował archeologię na Uniwersytecie Jagiellońskim w Krakowie, od 1916 r. aż do końca okresu międzywojennego był profesorem archeologii klasycznej na Uniwersytecie Lwowskim i ostatnim rektorem Uniwersytetu Jana Kazimierza. W okresie okupacji kierował wykładami w ramach tajnego Uniwersytetu Jana Kazimierza, zaś po wojnie został pracownikiem naukowym Uniwersytetu Wrocławskiego. Zob. np. Ziomecki 1998.

${ }^{32}$ DALO, f. 26, op. 5, spr. 713 (teczka osobowa K. Zakrzewskiego), ark. 58.

${ }^{33}$ Zob. m.in. Zakrzewski 1930; idem 1931; idem 1933a; idem 1933-1934: Zakrzewski 1935 (by ograniczyć się tylko do prac traktujących o historii późnego antyku i dziejach Bizancjum).

${ }^{34}$ Były to na przykład: „Późne cesarstwo rzymskie: dzieje i instytucje” (rok akademicki 1928/29), „Krótki zarys dziejów Bizancjum do połowy VIII w." (rok akademicki 1928/29), „Przegląd dziejów cesarstwa bizantyjskiego” (rok akademicki 1929/30), „Dzieje Bizancjum od śmierci Justynjana” (rok akademicki 1930/31), „Czasy Konstantyna Wielkiego” (rok akademicki 1932/33), „Upadek świata antycznego" (rok akademicki 1933/34). Pełną ich listę znaleźć można w cyklicznie wydawanych spisach wykładów pracowników Uniwersytetu Jana Kazimierza we Lwowie.

${ }^{35}$ Por. wspomniane w poprzednim przypisie wykazy wykładów na Uniwersytecie Jana Kazimierza we Lwowie.

${ }^{36}$ Asystentem starszym woluntariuszem przy katedrze archeologii klasycznej UJK Kazimierz Zakrzewski został mianowany w grudniu 1932 r. (DALO, f. 26, op. 5, spr. 713 [teczka osobowa K. Zakrzewskiego], ark. 79-81). 
Ryc. 2. Edmund Bulanda, autor (współautor?) referatu „O potrzebie katedry historji bizantyńskiej w Polsce ze szczególnym uwzględnieniem Uniwersytetu lwowskiego"

Źródło: ze zbiorów autora.

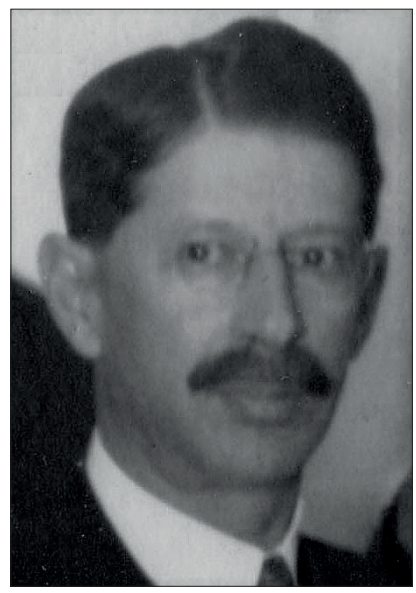

na wydziale) oraz profesorowie Stanisław Witkowski (1866-1950) ${ }^{37}$ i Edmund Bulanda. W dyskusji, która rozgorzała po tym wystąpieniu, najdobitniej wybrzmiał głos prof. Stanisława Zakrzewskiego (1873-1936; prywatnie - stryja Kazimierza) ${ }^{38}$, który zaproponował, by do wyboru komisji - z uwagi na dużą wagę zgłoszonej propozycji K. Chylińskiego i E. Bulandy - przystąpić dopiero na następnym posiedzeniu Rady wydziałowej. Jego wniosek został też przez Radę zaaprobowany ${ }^{39}$.

Do kwestii wrócono zatem na kolejnym zebraniu Rady Wydziału, które odbyło się po dwóch tygodniach, 29 listopada 1933 r. Sprawę referował prof. Edmund Bulanda, który przedstawił Radzie następujące wnioski: 1. Zwrócić się do Ministerstwa Wyznań Religijnych i Oświecenia Publicznego z prośbą o utworzenie katedry historii i kultury Bizancjum na Uniwersytecie Jana Kazimierza we Lwowie; 2. Wybrać komisję do spraw obsadzenia ewentualnej katedry - w jej skład mieliby wejść członkowie Komisji Historycznej oraz wspomniani wyżej profesorowie Stanisław Witkowski i Edmund Bulanda, jak również Witold Taszycki (1898-1979) ${ }^{40}$ i Jan Janów (1888-1952) ${ }^{41}$. Po krótkiej dyskusji, w której wzięli udział Stanisław

37 Stanisław Witkowski był jednym z najwybitniejszych polskich filologów klasycznych i historyków starożytności; od 1902 r. był profesorem filologii klasycznej Uniwersytetu Lwowskiego. Więcej na jego temat: Żuławska 1955; Królczyk 2007, s. 29-31.

38 DALO, f. 26, op. 5, spr. 713 (teczka osobowa K. Zakrzewskiego), ark. 64, 66, 84 i 95. Na temat Stanisława Zakrzewskiego zob. Błachowska 2007.

39 DALO, f. 26, op. 7, spr. 1364 (Wydział Humanistyczny, protokoły posiedzeń Rady Wydziału za rok akademicki 1933/34), ark. 26 verso.

40 Witold Taszycki był profesorem zwyczajnym filologii słowiańskiej i zarazem kierownikiem Zakładu Filologii Słowiańskiej Uniwersytetu Jana Kazimierza we Lwowie; por. Krawczuk 2004.

41 Jan Janów - profesor filologii ruskiej (= ukraińskiej) na Uniwersytecie Jana Kazimierza we Lwowie; zob. Witkowski 2000. 
Witkowski, Konstanty Chyliński i Jan Janów, Rada Wydziału Humanistycznego UJK jednomyślnie powzięła decyzję o poparciu przedstawionych jej wniosków ${ }^{42}$.

Zgodnie z wolą wyrażoną przez Radę i z własną deklaracją z 15 listopada prof. Edmund Bulanda przygotował stosowny memoriał, który miał uzasadniać ideę powołania do życia na lwowskiej Alma Mater katedry bizantynistyki ${ }^{43}$. Referat ten, zatytułowany „O potrzebie katedry historji i kultury bizantyńskiej w Polsce ze szczególnym uwzględnieniem Uniwersytetu lwowskiego", szczęśliwym zbiegiem okoliczności zachował się w Państwowym Archiwum Województwa Lwowskiego z siedzibą we Lwowie (ryc. 3) ${ }^{44}$. Cały dokument, datowany na 14 grudnia 1933 r., liczy dziewięć stron maszynopisu i składa się z czterech części, ponumerowanych cyframi rzymskimi. Ponieważ tekst ten nie jest szerzej w Polsce znany, pozwolę sobie w tym miejscu na jego dość szczegółowe omówienie, natomiast w zamieszczonym na końcu niniejszych rozważań Aneksie - na przytoczenie dokumentu in extenso.

W części I (s. 1-2), o charakterze wprowadzającym, Edmund Bulanda zapoznawał czytelnika z przedmiotem badań bizantynistyki. Uczony wyszedł z założenia, że dzieje Bizancjum, państwa „co do religji chrześcijańskiego, co do kultury greckiego", obejmują zasadniczo okres od założenia Konstantynopola w 330 r. do upadku tego miasta w roku 1453, choć zdarza się, że przedmiotem badań bizantynistów są również lata wcześniejsze (zwłaszcza w odniesieniu do rozwoju chrześcijaństwa w Cesarstwie Rzymskim), jak i późniejsze (dzieje Greków pod panowaniem tureckim). Uczeni koncentrują przy tym swoją uwagę nie tylko na historii politycznej, ale również na historii prawa, ustrojów politycznych, dziejach gospodarczych, historii Kościoła (w tym jego stosunków z katolicyzmem na Zachodzie) i bogatej kultury, będącej spuścizną tysiącletnich dziejów państwa wchodniorzymskiego. E. Bulanda podkreślał przy tym, że kultura bizantyńska promieniowała nie tylko na słowiańską część kontynentu, ale i na zachodnią część Europy, a świat grecki, bizantyński, bez wątpienia posiadał materialną i duchową przewagę nad światem zachodnim i to nie tylko w okresie formowania się chrześcijaństwa, ale także w dobie średniowiecza. Nawet europejski renesans pozostawał pod wyraźnym wpływem analogicznego prądu w świecie greckim.

${ }^{42}$ DALO, f. 26, op. 7, spr. 1364 (Wydział Humanistyczny, protokoły posiedzeń Rady Wydziału za rok akademicki 1933/34), ark. 29 verso.

${ }^{43}$ Przypomnijmy, że przygotowanie memoriału w sprawie utworzenia katedry wzięli na siebie profesorowie Konstanty Chyliński i Edmund Bulanda (zob. wyżej), tymczasem referat jest podpisany tylko przez drugiego $\mathrm{z}$ wymienionych. Nie wiadomo zatem, jaki był udział w jego powstaniu (i czy w ogóle) K. Chylińskiego.

${ }^{44}$ DALO, f. 26, op. 7, spr. 1311 (korespondencja z ministerstwem w sprawie utworzenia katedry historii Bizancjum), ark. 157-165. 

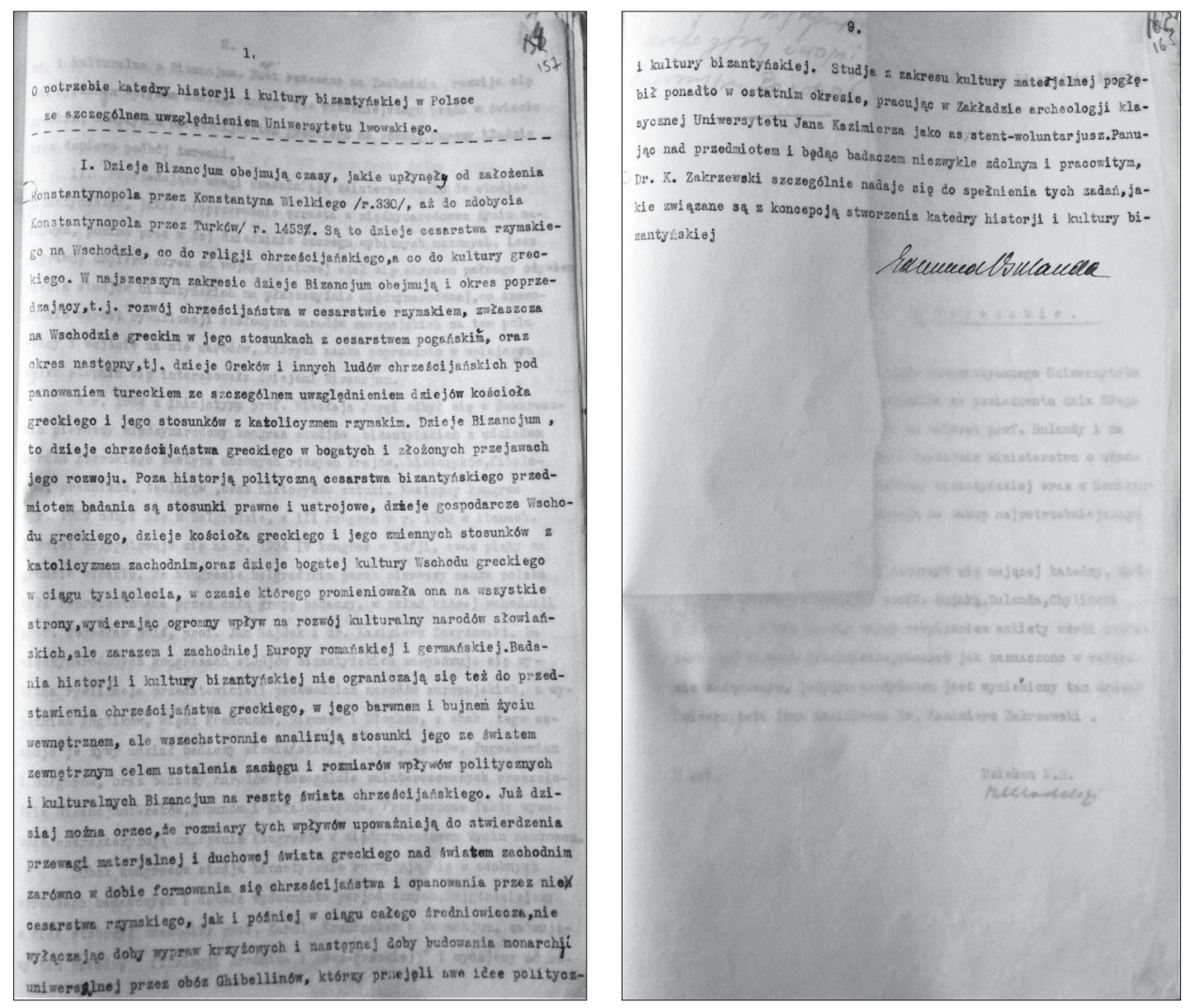

Ryc. 3. Pierwsza i ostatnia strona referatu E. Bulandy z jego podpisem; DALO, f. 26, op. 7, spr. 1311, ark. 157 i 165

Źródło: Państwowe Archiwum Województwa Lwowskiego we Lwowie.

Część II referatu prof. Edmunda Bulandy (s. 2-5) została poświęcona omówieniu ówczesnych badań nad dziejami Cesarstwa Wschodniorzymskiego, prowadzonych w Europie, szczególnie po zakończeniu I wojny światowej. Za punkt wyjścia posłużyły informacje na temat międzynarodowych kongresów studiów bizantynistycznych, na których pojawiają się badacze z Francji, Niemiec, Włoch, Rumunii, Grecji, Hiszpanii i krajów słowiańskich. Pierwszy taki kongres odbył się w 1924 r. w Bukareszcie, drugi - w 1927 w Belgradzie, a trzeci - trzy lata później w Atenach. W chwili, gdy Edmund Bulanda sporządzał swój referat, trwały przygotowania do kolejnego zjazdu w Sofii. W kongresie w stolicy Jugosławii wzięli już udział uczeni z Polski - profesor Wojsław Molè (1886-1973) z Uniwersytetu Jagiellońskiego w Krakowie ${ }^{45}$, wspomniany już wyżej profesor Jan Sajdak

${ }^{45}$ Wojsław (właściwie Vojeslav) Molè - Słoweniec z pochodzenia, badacz sztuki bizantyńskiej, od 1925 r. profesor historii sztuki na UJ; zob. Kalinowski 1976. 
z Uniwersytetu Poznańskiego oraz - reprezentujący Lwów - doktor Kazimierz Zakrzewski.

Następnie referent omówił najznaczniejsze europejskie ośrodki bizantynistyki i działających w tych ośrodkach uczonych, tudzież wydawane tam czasopisma. Na pierwszym miejscu wymienione zostało Monachium, w którym czynny był niegdyś Karl Krumbacher (1856-1909) ${ }^{46}$, uznawany za właściwego twórcę bizantynistyki jako nauki, wydawca znanego i niezwykle cenionego czasopisma „Byzantinische Zeitschrift”47. Dalej autor referatu wspomniał „Byzantinisch-Neugriechische Jarhbücher”, wychodzące pierwotnie w Berlinie, a później w Atenach ${ }^{48}$; belgijskie „Byzantion. Revue Internationale des Études byzantines” ${ }^{49}$, redagowane przez H. Grégoire'a ${ }^{50}$, a ponadto wydawnictwo „Acta Sanctorum” ${ }^{51}$. Wspomniany został również szereg czasopism włoskich i wydawanych we Włoszech, w tym periodyki kościelne (np. „Oriente e Roma” ${ }^{2}$, „Oriens Christianus”53), i świeckie (np. „Studi Bizantini e Neoellenici” ${ }^{4}$ ). Sporo miejsca zostało poświęcone badaniom prowadzonym w Rosji, głównie przedrewolucyjnej, gdyż po 1918 r. część ośrodków bizantynistycznych została tam zlikwidowana. Edmund Bulanda wymienił tu działalność Wasilija G. Wasiliewskiego (1838-1899) ${ }^{55}$, Nikodima P. Kondakowa (1844-1925) ${ }^{56}$, Fiodora I. Uspienskiego (1845-1928) ${ }^{57}$, Konstantina N. Uspienskie-

46 Karl Krumbacher - niemiecki bizantynista, od 1897 r. profesor w seminarium filologii środkowo- i nowogreckiej (Seminar für Mittel- und Neugriechische Philologie) Uniwersytetu w Monachium; zob. Kotłowska 2013.

47 „Byzantinische Zeitschrift” - jedno z najważniejszych czasopism w dziedzinie bizantynistyki, ukazuje się od 1892 r.; więcej na jego temat: Ceran 2002d.

${ }^{48}$ Czasopismo wychodziło od 1920 r.; por. Ceran 2002c.

${ }^{49}$ Czasopismo założone w 1924 r. przez H. Grégoire’a (Ceran 2002e).

${ }^{50}$ Henri Grégoire (1881-1964) - belgijski historyk, bizantynolog i filolog klasyczny, profesor Uniwersytetu w Brukseli; zob. Ceran 2002g.

${ }^{51}$ Wydawnictwo zapoczątkowane w 1643 r. w Antwerpii przez Jeana Bollanda (na jego temat zob. niżej, przyp. 89); por. Ceran 2002.

${ }_{52}$ Właściwy tytuł czasopisma brzmiał „Roma e l'Oriente”; zob. Croce 1990.

53 „Oriens Christianus. Römische Halbjahreshefte für die Kunde des christlichen Orients” ukazuje się od 1901 r. (dziś pod zmienionym tytułem: „Oriens Christianus. Hefte für die Kunde des christlichen Orients").

${ }^{54}$ Włoskie „Studi Bizantini” ukazywały się od 1924 roku (od 1931 r. pod tytułem „Studi Bizantini e Neoellenici”, dziś „Rivista di Studi Bizantini e Neoellenici”); por. Studi Bizantini 2020.

${ }_{55}$ Wasilij G. Wasiliewskij - rosyjski bizantynista, profesor w katedrze wieków średnich Uniwersytetu Petersburskiego; por. Ceran 2002m.

${ }^{56}$ Nikodim P. Kondakow - rosyjski bizantynolog, profesor Uniwersytetu w Petersburgu, a po I wojnie światowej - Uniwersytetu w Sofii; zob. Ceran 2002i.

${ }^{57}$ Fiodor I. Uspienskij - rosyjski bizantynista, profesor Uniwersytetu Noworosyjskiego w Odessie, od 1895 r. dyrektor Rosyjskiego Instytutu Archeologicznego w Konstantynopolu; zob. Ceran $2002 \mathrm{k}$. 
go (1874-1917) ${ }^{58} \mathrm{i}$ innych, wskazując przy tym na doniosłą rolę, jaką na gruncie rosyjskim odegrało bardzo wartościowe czasopismo „Wizantijskij wremiennik” ${ }^{59}$. Wreszcie krótkie wzmianki poświęcone zostały studiom bizantynistycznym prowadzonym w Grecji i w Turcji.

W dalszej części referatu Edmund Bulanda przeszedł do wymienienia najważniejszych uniwersyteckich katedr dziejów Bizancjum, uwzględniając tu Paryż (Sorbona), Brukselę, Rzym, Padwę, Ateny, Tesaloniki, Sofię, Belgrad, Graz, Bukareszt, Kluż i Czerniowce (w okresie międzywojennym miasto rumuńskie) oraz uniwersytety niemieckie (Monachium, Berlin, Lipsk), w których co prawda nie było wówczas odrębnych katedr historii bizantynistyki, niemniej studia nad historią Bizancjum uprawiano z powodzeniem w innych katedrach, np. filologii bizantyńskiej czy też historii starożytnej. Na zakończenie tej części pracy lwowski profesor przypomniał najważniejsze nazwiska w światowej bizantynistyce, wspominając tak osoby już nieżyjące (A.N. Rambaud ${ }^{60}$, G. Schlumberger ${ }^{61}$, J.B. Bury ${ }^{62}$, K. Krumbacher ${ }^{63}$, K. Uspienskij ${ }^{64}$, S. Lampros ${ }^{65}$ ), jak i wówczas nadal czynne naukowo (Ch. Diehl ${ }^{66}$, N. Jorga ${ }^{67}$, M. Rostowcew ${ }^{68}$ i inni).

Część III referatu (s. 5-7) poświęcona została argumentom na rzecz utworzenia katedry historii Bizancjum w Polsce. Biorąc pod uwagę wszystko to, co zostało już przez niego wyżej powiedziane, Edmund Bulanda uznał za rzecz niezmiernie pożądaną stworzenie takiej katedry na jednym z uniwersytetów w naszym kraju i w konsekwencji - prowadzenie stałych wykładów akademickich z dziejów Bi-

\footnotetext{
${ }^{58}$ Konstantin N. Uspienskij - rosyjski bizantynista, docent Uniwersytetu Moskiewskiego; zob. Sjuzmow 1973.

${ }^{59}$ Rosyjskie czasopismo ukazujące się w Petersburgu/Piotrogradzie/Leningradzie od $1894 \mathrm{r}$. (zob. Ceran 2002n).

${ }^{60}$ Alfred Nicolas Rambaud (1842-1905) - francuski historyk i bizantynolog, profesor paryskiej Sorbony; zob. Pellisson 2020.

${ }^{61}$ Gustave Schlumberger (1844-1929) - francuski mediewista, bizantynolog i numizmatyk; por. Ceran 2002j.

${ }^{62}$ John Bagnell Bury (1861-1927) - irlandzki historyk i filolog klasyczny, profesor uniwersytetu w Cambridge; zob. Ceran 2002b.

${ }^{63}$ Zob. wyżej, przyp. 46.

${ }^{64}$ Zob. wyżej, przyp. 58.

${ }^{65}$ Spiridon Lambros (1851-1919) - grecki historyk i bizantynolog, w latach 1916-1917 premier Grecji.

${ }^{66}$ Charles Diehl (1859-1944) - historyk i bizantynolog francuski, wykładowca paryskiej Sorbony; zob. Ceran $2002 \mathrm{f}$.

${ }^{67}$ Nicolas Jorga (Nicolae Iorga; 1871-1940) - rumuński historyk, profesor Uniwersytetu w Bukareszcie; por. Ceran 2002h.

${ }^{68}$ Michaił I. Rostowcew (1870-1952) - wybitny rosyjski historyk starożytności, profesor Uniwersytetu Petersburskiego (od 1908 r.); po rewolucji październikowej przebywał na emigracji politycznej, początkowo w Anglii, a ostatecznie w Stanach Zjednoczonych, gdzie uzyskał profesurę na Uniwersytecie w Yale. Zob. np. Schneider 2012.
} 
zancjum, dalej zebranie potrzebnej literatury przedmiotu i wreszcie wychowanie młodych adeptów tej dyscypliny oraz włączenie nauki polskiej w międzynarodowe studia bizantynistyczne, jak również stworzenie, w miarę możliwości, polskiego czasopisma z dziedziny historii i kultury bizantyńskiej. W odczuciu Edmunda Bulandy w realiach polskich bardziej pożądane byłoby utworzenie katedry historii Bizancjum niż katedry „bizantynistyki filologicznej”, gdyż polscy filologowie klasyczni (Leon Sternbach ${ }^{69}$, Jan Sajdak ${ }^{70}$, Tadeusz Sinko ${ }^{71}$, Aleksander Turyn ${ }^{72}$ ), z których każdy zna przecież doskonale źródła bizantyńskie, w swoich badaniach często wchodzą na grunt wschodniorzymski. Tymczasem w przypadku historii starożytnej takiego związku nie ma, zatem powinny zostać wyodrębnione historyczne (i archeologiczne) studia bizantyńskie, zwłaszcza że i katedr historii starożytnej nie było wówczas w Polsce zbyt wiele ${ }^{73}$.

W opinii referenta utworzenie postulowanej katedry umożliwiłoby młodym badaczom studia nad stosunkami Bizancjum i średniowiecznej Polski czy też wpływami chrześcijaństwa wschodniego na materialną i duchową kulturę naszego kraju, co jak dotąd nie zostało dostatecznie dobrze zbadane. E. Bulanda był całkowicie przekonany, że „dopiero szerokie uwzględnienie studjów bizantyńskich pozwoli na dokładne określenie miejsca Polski w polityce i cywilizacji średniowiecznej”, jak również że konieczna jest w Polsce pogłębiona znajomość chrześcijaństwa wschodniego.

Edmund Bulanda przeszedł wreszcie do jednego z najważniejszych punktów swojego referatu, a mianowicie do odpowiedzi na pytanie, dlaczego właśnie Lwów (i zarazem lwowska wszechnica) powinien zostać siedzibą nowej katedry uniwersyteckiej. Wynikało to wprost - w opinii referenta - z historii Lwowa, który jako jedyne z ówczesnych dużych miast polskich w czasach Rusi Halickiej znajdował się na terenie bezpośrednio podlegającym wpływom bizantyjskim, po przyłączeniu do Polski w XIV w. pozostawał w ścisłych związkach z Cesarstwem Bizantyjskim, zaś po jego upadku - z chrześcijaństwem wschodnim pod panowaniem tureckim. Lwów powinien stać się, jak przekonywał prof. Bulanda, miejscem obrad między-

69 Zob. wyżej, przyp. 6.

70 Zob. wyżej, przyp. 8.

71 Tadeusz Sinko (1877-1966) - wybitny polski filolog klasyczny, profesor Uniwersytetu Lwowskiego oraz Uniwersytetu Jagiellońskiego w Krakowie; zob. Turasiewicz 1996-1997.

72 Aleksander Turyn (1900-1981) - polski filolog klasyczny i bizantynolog, profesor Uniwersytetu Warszawskiego, po wojnie na emigracji w USA; por. Plezia 1991.

73 W okresie międzywojennym w Polsce takie katedry istniały na uniwersytetach w Warszawie (od 1922 r.), we Lwowie (od 1921 r.), w Krakowie (od 1922 r.), w Lublinie (od 1919 r.) i - przejściowo - w Poznaniu (od 1919 do 1922 r.); katedry historii starożytnej nie udało się natomiast stworzyć na uniwersytecie w Wilnie, choć pewne próby były w tym kierunku czynione w 1929 r., a jedną z kandydatur był doc. Kazimierz Zakrzewski: zob. DALO, f. 26, op. 5, spr. 2016 (teczka osobowa K. Chylińskiego), ark. 251. Nie wiadomo jednak, dlaczego ta inicjatywa nie zakończyła się sukcesem. 
narodowego kongresu studiów bizantyńskich, o ile organizacja takowego zostałaby Polsce powierzona. I wreszcie - zdaniem Edmunda Bulandy katedra bizantynologiczna mogłaby zwiększyć oddziaływanie polskiego uniwersytetu we Lwowie na młodzież ukraińską i pociągnąć ją „do twórczej współpracy z nauką polską”, tym bardziej że społeczność ukraińska była bardzo zainteresowana związkami historycznymi Bizancjum z Rusią ${ }^{74}$.

W czwartej, ostatniej, części referatu (s. 8-9) Edmund Bulanda dość szczegółowo zaprezentował kandydata posiadającego odpowiednie kwalifikacje naukowe do objęcia katedry w przypadku jej utworzenia - dr. Kazimiera Zakrzewskiego, wymieniając jego najważniejsze publikacje dotyczące schyłku starożytności i dziejów Bizancjum.

Otrzymawszy od Edmunda Bulandy podpisany referat, profesor Teofil Modelski ${ }^{75}$, ówczesny dziekan Wydziału Humanistycznego UJK, zgodnie z decyzją Rady wydziałowej wystosował specjalne pismo do Ministerstwa Wyznań Religijnych i Oświecenia Publicznego w Warszawie $(1042 / 33)^{76}$. W piśmie została zawarta informacja, że Rada Wydziału w dniu 29 listopada 1933 r. uchwaliła jednomyślnie na wniosek prof. Bulandy wystąpić do Ministerstwa z prośbą o utworzenie katedry historii i kultury bizantyńskiej na Uniwersytecie Jana Kazimierza we Lwowie wraz z seminarium i o przyznanie stałej dotacji na zakup najpotrzebniejszych sprzętów. Dziekan poinformował również o wybraniu komisji ds. obsady przyszłej katedry (z podaniem nazwisk), mającej się zająć rozpisaniem ankiety adresowanej do profesorów pokrewnych dyscyplin naukowych, jak również o tym, że jedynym kandydatem członków Rady Wydziału do jej objęcia jest dr. K. Zakrzewski (ryc. 4).

Odpowiedź z Warszawy nadeszła w 1934 roku. Niestety nie była ona dla Lwowian pomyślna. Ministerstwo Wyznań Religijnych i Oświecenia Publicznego decyzją o numerze IV NP13524/34 nie uwzględniło wniosku Rady Wydziału Humanistycznego UJK we Lwowie ${ }^{77}$, co zarazem oznaczało, że katedra historii i kultury Bizancjum nie została utworzona (ryc. 5). Nie udało mi się niestety jak dotąd ustalić, jakie argumenty zostały użyte przez ministra do uzasadnienia odmownej decyzji. Roman Ławrećkyj, autor dysertacji poświęconej nauce historycznej na Uniwersytecie Lwowskim w okresie dwudziestolecia międzywojennego, sądzi, że

${ }^{74}$ Dowodem tego może być, między innymi, wspomniany wyżej zakup publikacji K. Krumbachera przez władykę Szeptyckiego dla ukraińskiej placówki muzealnej we Lwowie (zob. przyp. 9).

75 Teofil Modelski (1881-1967) - historyk i archiwista, w okresie międzywojennym profesor historii na Uniwersytecie Stefana Batorego w Wilnie i na Uniwersytecie Jana Kazimierza we Lwowie, po wojnie profesor Uniwersytetu Wrocławskiego; zob. Śreniowska 1994.

${ }^{76}$ DALO, f. 26, op. 7, spr. 1311 (korespondencja z ministerstwem w sprawie utworzenia katedry historii Bizancjum), ark. 155 i 167.

77 DALO, f. 26, op. 7, spr. 1311 (korespondencja z ministerstwem w sprawie utworzenia katedry historii Bizancjum), ark. 154. 
jedną z przyczyn były kłopoty finansowe państwa, niemniej nie przytacza żadnych źródeł, które by taką opinię mogły poprzeć ${ }^{78}$. Nie można też do końca wykluczyć, że odmowa ta miała pewien podtekst polityczny, wszak Edmund Bulanda w swoim referacie zakładał możliwość współpracy na gruncie uniwersyteckim z mło-

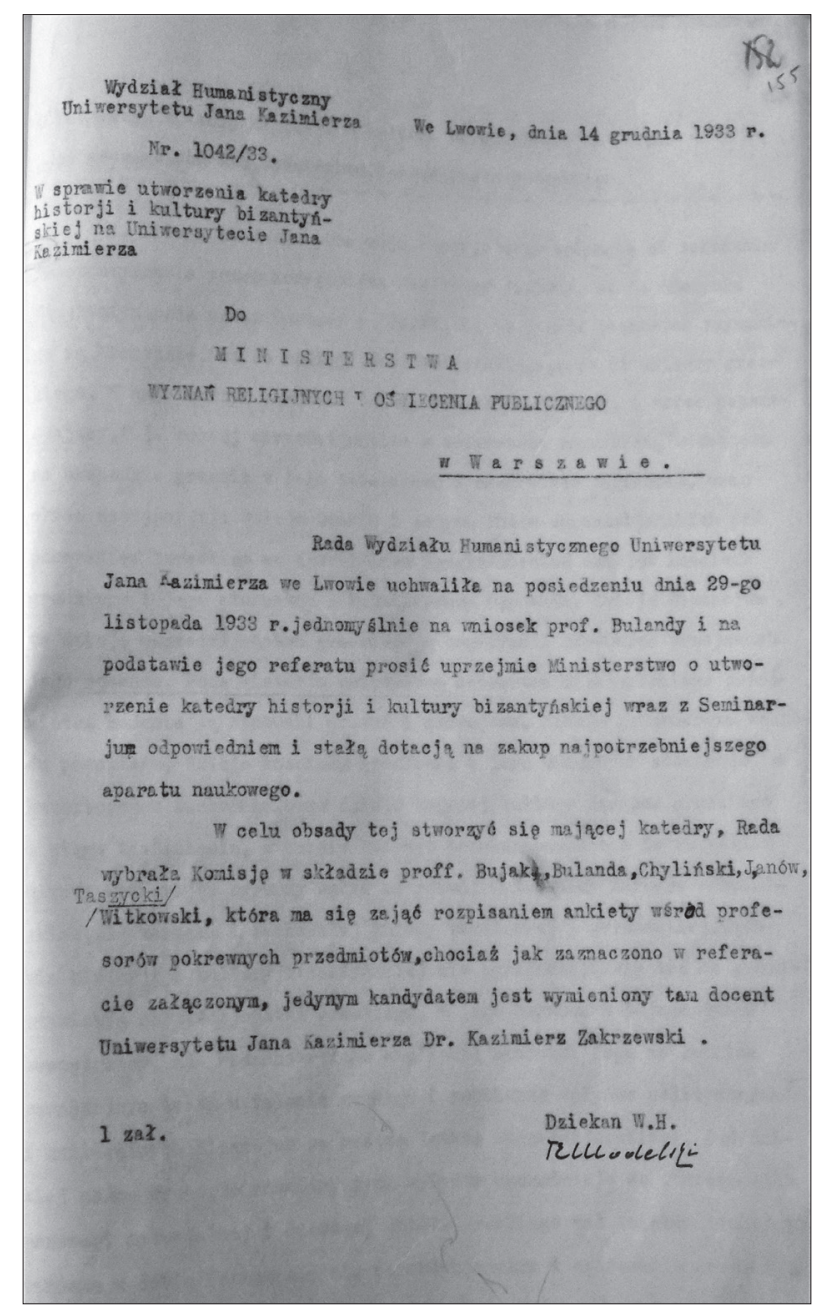

Ryc. 4. Pismo dziekana Wydziału Humanistycznego UJK, prof. Modelskiego, do Ministerstwa WRiOP z prośbą o utworzenie katedry historii i kultury Bizancjum na lwowskiej Alma Mater; DALO, f. 26, op. 7, spr. 1311, ark. 155

Źródło: Państwowe Archiwum Województwa Lwowskiego we Lwowie.

${ }^{78}$ Ławrećkyj 2000, s. 64. 


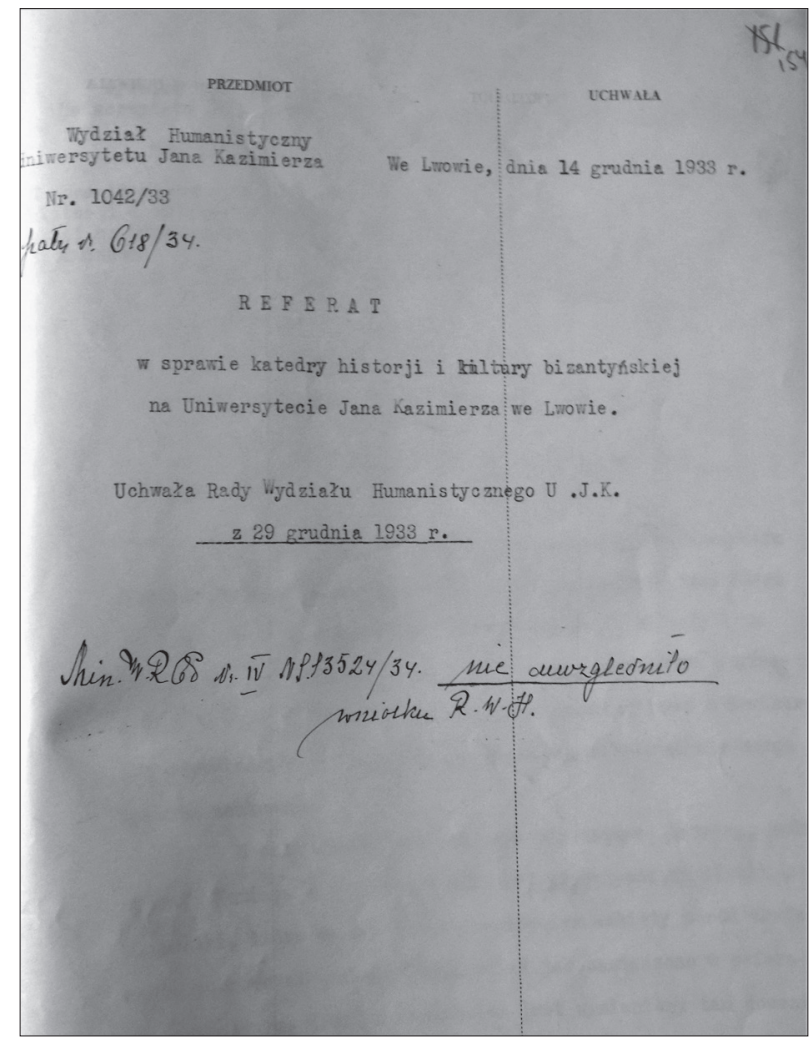

Ryc. 5. Informacja o odmownej decyzji Ministerstwa; DALO, f. 26, op. 7, spr. 1311, ark. 154; zwraca uwagę błędnie napisana data uchwały Rady Wydziału Humanistycznego UJK - na dokumencie widnieje 29 grudnia 1933, powinno być 29 listopada $1933 \mathrm{r}$.

Źródło: Państwowe Archiwum Województwa Lwowskiego we Lwowie.

dzieżą ukraińską; postawa taka, w dobie rosnących w tym okresie w Polsce i w całej Europie nacjonalizmów, mogła być negatywnie oceniona przez czynniki rządowe. Być może dalsze poszukiwania archiwalne, w tym w Archiwum Akt Nowych w Warszawie, pozwolą znaleźć odpowiedź na ważne przecież pytanie o przyczyny niepowodzenia lwowskiej inicjatywy.

Kazimierz Zakrzewski nie został zatem pierwszym w Polsce profesorem historii Bizancjum na lwowskiej Alma Mater. Przez jakiś czas pracował jeszcze w charakterze starszego asystenta woluntariusza przy katedrze archeologii klasycznej UJK, u boku Edmunda Bulandy, prowadząc wykłady z dziejów Bizancjum i późnego Rzymu oraz ćwiczenia $\mathrm{z}$ historii starożytnej. To, co nie udało się we Lwowie, zdołano jednak wkrótce zrealizować na Uniwersytecie Warszawskim. W 1935 r. powołano tam do życia Katedrę Historii Bizancjum, pierwszą w Polsce. Jej kierow- 
nictwo powierzono, przy znaczącym udziale profesora Oskara Haleckiego ${ }^{79}$, właśnie Kazimierzowi Zakrzewskiemu, który zdecydował się przyjąć przedstawioną mu ofertę i przenieść się do Warszawy ${ }^{80}$. Wkrótce udało mu się zebrać wokół siebie dość liczne grono słuchaczy; pojawili się także jego pierwsi uczniowie. Była wśród nich Halina Evert-Kappesowa (1904-1985) ${ }^{81}$, która po tragicznej śmierci swojego mistrza, rozstrzelanego w dniu 11 marca 1941 r. w Palmirach ${ }^{82}$, już po wojnie kontynuowała dzieło zapoczątkowane przez Kazimierza Zakrzewskiego, choć nie w Warszawie, lecz na nowo utworzonym uniwersytecie w Łodzi. Łódź stała się zatem w okresie powojennym centrum polskiej bizantynologii ${ }^{83}$.

Natomiast w samym Lwowie pomysł zgłoszony w początkach lat 30 . XX wieku przez Konstantego Chylińskiego i Edmunda Bulandę, odłożony jednak - wobec negatywnej opinii ministerstwa - na bliżej nieokreśloną przyszłość, znalazł swoją kontynuację wiele lat później, w zupełnie innych okolicznościach geopolitycznych. Oto w 1998 r., na ukraińskiej już uczelni, powołano do życia Katedrę Bizantynologii (Kafedra Wizantolohiji), działającą w strukturach Wydziału Historycznego Uniwersytetu im. Iwana Franki. Jej kierownikiem został Wasyl P. Otkowycz (1950-2017) ${ }^{84}$. W 2004 r., po dokonaniu pewnych zmian organizacyjnych, katedrę tę przekształcono w Katedrę Historii Wieków Średnich i Bizantynistyki (Kafedra Istoriji Serednich Wikiw i Wizantynistyky), która funkcjonuje po dziś dzień. Jej pierwszym kierownikiem została Rajisa W. Szyjan (ur. 1947), a od 2006 r. funkcję te pełni Leontij W. Wojtowycz (ur. 1951) ${ }^{85}$. Wśród licznych prac wydanych przez pracowników katedry, na wspomnienie zasługuje opracowany przez nich, wespół z kolegami z Charkowa, obszerny uniwersytecki podręcznik w języku ukraińskim do dziejów Bizancjum ${ }^{86}$.

W ten sposób pomysł polskich uczonych, zrodzony w okresie międzywojennym, kiedy Lwów należał do Polski, a Uniwersytet Jana Kazimierza był prężną uczelnią polską, znalazł nieoczekiwanie swoje urzeczywistnienie w realiach niepodległego państwa ukraińskiego i na ukraińskiej już uczelni. Nieodgadnione są - jak widać - ścieżki, po których przechadza się Klio, muza historii.

79 Oskar Halecki (1891-1973) - wybitny polski historyk, zajmujący się również dziejami średniowiecznego Bizancjum, do 1939 r. profesor Uniwersytetu Warszawskiego, po wojnie na emigracji w Stanach Zjednoczonych. Por. np. Dąbrowska (red.) 2012-2014.

${ }^{80} \mathrm{Na}$ temat warszawskiego okresu w życiu K. Zakrzewskiego zob. Halecki 1945, s. 312-313; Rutkowski 2015.

${ }^{81}$ Halina Evert-Kappesowa (1904-1985) - uczennica i asystentka Kazimierza Zakrzewskiego na UW, po wojnie czynna na Uniwersytecie Łódzkim, na którym w 1957 r. doprowadziła do utworzenia Zakładu Historii Bizancjum; zob. Ceran 1988.

${ }^{82}$ Szerzej na ten temat: Borkowski 2015, s. 301-306.

${ }^{83}$ Por. np. Kompa 2016, zwłaszcza s. 157 nn.

${ }^{84}$ Lyljo 2011.

${ }^{85}$ Oswińskyj 2011.

${ }^{86}$ Soroczan i Wojtowycz (red.) 2011. 


\title{
ANEKS
}

W dołączanym do niniejszego opracowania Aneksie znajdzie Czytelnik całość tekstu referatu sporządzonego w grudniu 1933 roku przez Edmunda Bulandę i dotyczącego kwestii utworzenia katedry bizantynistyki na Uniwersytecie Jana Kazimierza we Lwowie. Oryginał, w postaci maszynopisu, z odręcznym podpisem E. Bulandy, jest przechowywany w Państwowym Archiwum Obwodu Lwowskiego we Lwowie, w zespole (fond) „Uniwersytet Lwowski”, w jednostce (opis) „Wydział Filozoficzny/Humanistyczny" (DALO, f. 26, op. 7, spr. 1311, ark. 157-165).

Przy publikacji referatu E. Bulandy ograniczono do minimum ingerencje redaktorskie. Pozostawiono zatem charakterystyczne dla epoki zwroty językowe i formy ortograficzne, nawet jeśli różnią się nieco od współczesnych norm języka polskiego, dokonując jedynie pewnych drobnych korekt w interpunkcji. Nieliczne błędne zapisy nazw geograficznych oraz nazwisk uczonych zostały sprostowane $\mathrm{w}$ przypisach. Również w przypisach podano informacje na temat wymienianych przez Edmunda Bulandę bizantynistów, o ile informacja taka nie pojawiła się już wcześniej w tekście głównym niniejszego artykułu.

\author{
(strona 1) \\ O potrzebie katedry historji bizantyńskiej w Polsce \\ ze szczególnym uwzględnieniem Uniwersytetu lwowskiego
}

I. Dzieje Bizancjum obejmują czasy, jakie upłynęły od założenia Konstantynopola przez Konstantyna Wielkiego (r. 330), aż do zdobycia Konstantynopola przez Turków (r. 1453). Są to dzieje cesarstwa rzymskiego na Wschodzie, co do religji chrześcijańskiego, a co do kultury greckiego. W najszerszym zakresie dzieje Bizancjum obejmują i okres poprzedzający, t.j. rozwój chrześcijaństwa w cesarstwie rzymskiem, zwłaszcza na Wschodzie greckim w jego stosunkach z cesarstwem pogańskiem, oraz okres następny, tj. dzieje Greków i innych ludów chrześcijańskich pod panowaniem tureckiem ze szczególnym uwzględnieniem dziejów kościoła greckiego i jego stosunków z katolicyzmem rzymskim. Dzieje Bizancjum, to dzieje chrześcijaństwa greckiego w bogatych i złożonych przejawach jego rozwoju. Poza historją polityczną cesarstwa bizantyńskiego przedmiotem badania są stosunki prawne i ustrojowe, dzieje gospodarcze Wschodu greckiego, dzieje kościoła greckiego i jego zmiennych stosunków z katolicyzmem zachodnim oraz dzieje bogatej kultury Wschodu greckiego w ciągu tysiąclecia, w czasie którego promieniowała ona na wszystkie strony, wywierając ogromny wpływ na rozwój kulturalny narodów słowiańskich, ale zarazem i zachodniej Europy romańskiej i germańskiej. Badania historii i kultury bizantyńskiej nie ograniczają się też do przedstawienia chrześcijaństwa greckiego, w jego barwnem i bujnem życiu wewnętrznym, ale wszechstronnie analizują stosunki jego ze światem zewnętrznym celem ustalenia zasięgu i rozmiarów wpływów politycznych i kulturalnych Bizancjum na resztę świata chrześcijańskiego. Już dzisiaj można orzec, że rozmiary tych wpływów upoważniają do stwierdzenia przewagi materialnej i duchowej świata greckiego nad światem zachodnim zarówno w dobie formowania się chrześcijaństwa i opanowania przez nie cesarstwa rzymskiego, 
jak i później w ciągu całego średniowiecza, nie wyłączając doby wypraw krzyżowych i następnej doby budowania monarchji uniwersalnej przez obóz Ghibellinów, którzy przejęli swe idee politycz-

(strona 2)

-ne i kulturalne z Bizancjum. Nawet renesans na Zachodzie rozwija się pod wyraźnym wpływem analogicznego, ale wcześniejszego prądu w świecie greckim, a wpływom chrześcijaństwa greckiego na rozwój Europy kładzie kres dopiero podbój turecki.

II. Poprzedzające uwagi uzasadniają zainteresowanie do studjów bizantyńskich, jakie nieprzerwanie wzrasta $\mathrm{w}$ międzynarodowem życiu naukowym, pomimo prac $\mathrm{w}$ tej dziedzinie szeregu wybitnych uczonych. Lecz naprawdę dopiero okres od wojny światowej stał się okresem pełnego ożywienia studjów bizantyńskich na płaszczyźnie międzynarodowej, co spowodowało wzrost rywalizacji czołowych narodów europejskich na tem polu pracy i wejście na nie narodów, których nauka poprzednio w mniejszym tylko stopniu się interesowała dziejami Bizancjum.

W r. 1924 z inicjatywy prof. Mikołaja Jorgi odbył się w Bukareszcie pierwszy międzynarodowy kongres studiów bizantyńskich z udziałem bardzo szerokiego zastępu uczonych różnych krajów, historyków, filologów, prawników, teologów oraz historyków sztuki. Następny kongres w r. 1927 odbył się w Belgradzie, a III kongres w r. 1930 w Atenach. Z kolei przygotowuje się na r. 1934 IV kongres w Sofji oraz piąty na gruncie włoskim. Na kongresie belgradzkim poraz [sic!] pierwszy nauka polska była reprezentowana przez całą grupę badaczy, w skład której wchodzili prof. Wojesław Molé ${ }^{87}$, prof. Jan Sajdak i dr. Kazimierz Zakrzewski. Na międzynarodowych kongresach studjów bizantyńskich zarysowuje się wybitna rywalizacja przedstawicieli przewodnich narodów europejskich, z wyjątkiem Anglików, więc: Francuzów, Niemców i Włochów, a obok tego cechuje je żywy udział badaczy słowiańskich: Rosjan, Czechów, Jugosłowian i Bułgarów oraz badaczy narodów szczególnie zainteresowanych przeszłością Bizancjum: Greków, Rumunów i Katalończyków. Przytoczone fakty wymownie charakteryzują znaczenia Kongresów w międzynarodowem życiu naukowem.

Obok kongresów studja bizantyńskie rozwijają się w osobnych ośrodkach badawczych i dokoła wydawnictw perjodycznych. Najgłośniejszy z nich stworzył znakomity prof. Karol Krumbacher w Monachjum, zajmujący tam katedrę "filologji średnio- i nowo-greckiej" i wydający od ro-

(strona 3)

-ku 1892 "Byzantinische Zeitschrift", wychodzące od tego czasu regularnie i grupujące na swych łamach poważny zastęp filologów, historyków i historyków sztuki. Drugie czasopismo tego typu "Byzantisch-Neugriechische Jahrbücher", wydawane od r. 1920 przez Greka Beêsa (czyt. Veis) ${ }^{88}$ w Berlinie przeniósł wydawca obecnie do Aten. W Belgji OO. Bollandyści uprawiają studia nad chrześcijaństwem greckiem od XVII w. (J. Bolland † 1566) ${ }^{89}$ i od r. 1643 wydają Acta Sanctorum, dotąd jeszcze nie ukończone (dotychczas około 60 tomów) a ponadto od r. 1882 Analecta Bollandiana. W ślad za nimi idzie nauka świecka. W r. 1931 rząd belgijski utworzył "Institut de Philologie et l'Histoire Orientale", a równocześnie założono przy bibliotece państwowej "Office biblio graphique des Études byzantines et slaves”. Od r. 1924 uczony belgijski H. Grégoire wydaje Byzantion - Revue Internationale des Études byzantines. W wydawnictwie tem

${ }^{87}$ Poprawny zapis nazwiska uczonego: Molè.

${ }^{88}$ Nikos A. Bees (Veis; ok. 1882-1958) - grecki bizantolog, filolog i polityk.

${ }^{89}$ Jean Bolland (1596-1665) - urodzony w Belgii jezuicki historyk i hagiograf, twórca zbioru żywotów świętych „Acta Sanctorum” (podana w referacie data jego śmierci jest błędna); zob. Ruland 1876. 
wypowiadają się też liczni uczeni francuscy, którzy, zajmując szereg katedr nie stworzyli własnego zewnętrznego ośrodka studiów bizantyńskich.

Silne ośrodki badawcze chrześcijaństwa greckiego powstały w Rzymie, co jest zupełnie zrozumiałe w związku ze wzrastającym zainteresowaniem Watykanu zagadnieniami kościoła wschodniego i unji kościelnej. Papieski Instytut Studjów Wschodnich pod przewodnictwem biskupa d'Herbigny wydaje od r. 1923 swoją monografję pt. Orientalia Christiana. "Collegio Pio del Campo Santo Teutonico" skupiające duchownych uczonych niemieckich wydaje od r. 1901 „Oriens Christianus”. Bazyljanie z Grottaferrata wydają czasopismo „Oriente e Roma”. Z tą działalnością ośrodków kościelnych rywalizuje świecki ośrodek naukowy, a mianowicie Instituto per l'Europa Orientale, wydający od r. 1925 "Studi Bizantini e Neoellenici”. Ponadto zaś wychodzi jeszcze w Rzymie popularno-naukowe czasopismo do dziejów chrześcijaństwa greckiego p.t.: "B essarione" (od r. 1896).

(strona 4)

W Grecji w r. 1909 Towarzystwo Bizantynologów zaczęło wydawać czasopismo "Byzantis”. Po wojnie przekształciło się w „Towarzystwo studjów bizantyńskich” i wydaje regularnie swój biuletyn.

W Sowietach dawniejsze żywe ośrodki studjów bizantyńskich zostały częściowo rozbite w dobie rewolucji. Ze względu na żywe zainteresowanie, jakiem studja historii i kultury bizantyńskiej cieszyły się zawsze w Rosji, nie od rzeczy będzie wspomnieć o dorobku nauki rosyjskiej na tem polu. Jest on bardzo znaczny, zarówno co do ilości uczonych dużej miary, zajmujących się studiami bizantyńskiemi, jak co do osiągniętych przez nich wyników. W. G. Wasilewskij (1838-99) profesor Uniwersytetu petersburskiego torował drogi, któremi poszli inni, N. P. Kondakow († 1925), Th. I. Uspenskij, Eołow, Kułakowskij, Szestakow, K. N. Uspenskij, Wasiliew i tylu innych. Od r. 1894 Rosyjska Akademia Umiejętności wydawała "Wizantijskij Wremennik" (wychodzi także i po wojnie pod redakcją Teodora Unspenskiego), dorównujący "Byzantinische Zeitschrift” pod względem bogactwa zawartego materjału. Po rewolucji Akademja Umiejętności w Leningradzie powołała do życia za sprawą Teodora Uspienskiego "Komisję Konstantyna Porfirogenety" dla studjów bizantyńskich, która działa nadal jako "rosyjsko-bizantyńska komisja historyczno-słownikowa" i między inn[ymi] prowadzi prace nad historjografą bizantyńską. Uczeni emigracyjni skupili się w Pradze w "Instytucie im. Kondakowa" i od r. 1927 wydają periodyk p.t.: "Seminarjum Kondakovianum". Pod ich wpływem powstał i czeski ośrodek studjów bizantyńskich, a mianowicie Komisja bizantynologiczna przez Instytucie Słowiańskim w Pradze, która od r. 1929 wydaje imponujące czasopismo p.t. "Byzantino slavica”.

Wreszcie należałoby wspomnieć o pracach zakonu Asumpcjonistów w Kadikeǔi ${ }^{90}$ (dawn. Chalkedon) koło Konstantynopola ze względu na ruchliwość tego ośrodka, który wydaje od r. 1897 kwartalnik „Echos d'Orient”, a ponadto “Oriens Christianus” (różny od niemieckiego wydawnictwa pod tym tytułem wydawanego w Cittá del Vaticano). Pozatem Instytut z Kadikeui wydaje szereg innych publikacyj.

(strona 5)

Wobec tak wielkiego rozrostu studjów bizantyńskich nic dziwnego, że wzrasta w różnych krajach ilość katedr uniwersyteckich, poświęconych tym studjom. Katedry historji bizantyńskiej istnieją obecnie m.inn. w Paryżu (na Sorbonie, a obok niej w uczelni dla specjalistów tzw. "École pratique des Hautes Études” katedry chrześcijaństwa bizantyńskiego oraz filologji klasycznej), w Brukseli (po-

${ }^{90}$ Poprawna współczesna nazwa turecka brzmi: Kadıköy. 
łączona w rękach H. Grégoire z katedrą literatury greckiej), w Rzymie, w Atenach i w Tesalonice, w Sofji, a pod nazwą katedr bizantynologji w Belgradzie (profesor honorowy Anastasijević), w Rumunji na uniwersytetach w Cluj (dawniej Kolozsvar) i w Czerniowcach, a ponadto istnieje szereg katedr filologji bizantyńskiej (Monachjum, Berlin, Lipsk, Graz, Bukareszt, Padwa itd). Uderza, że w Niemczech niema katedr, określonych jako katedry historji bizantyjskiej, co tłumaczy się tem, że niemieccy historycy Bizancjum zajmują katedry inne (filologji bizantyńskiej w Monachjum, - wybitny historyk ustroju i życia gospodarczego Bizancjum, prof. Dölger, - historji starożytnej, historji wschodniej Europy), na których, wobec istnienia szeregu katedr równoległych, mogą oddawać się wyłącznie pracy naukowej i pedagogicznej w zakresie swej specjalności.

O znaczeniu studjów bizantyńskich we współczesnej kulturze umysłowej Europy, świadczy też waga nazwisk szeregu wielkich uczonych, którzy zabłysnęli na tem polu, stając się chlubą swoich narodów, że wymienimy tylko z pośród już nieżyjących: Francuzów Rambaud i Schlumberger, Anglika J.B. Bury, Niemca Krumbachera, Rosjanina K. Uspieńskiego, Greka Lamprosa, których godnymi następcami wśród żyjących są Charles Diehl, Jorga, Millet, Strzygowski, Rostowcew itd. Do wymienionych dla przykładu nazwisk możnaby [sic!] dołączyć jeszcze szereg innych, niemal równie świetnych.

III. Wobec faktów wyżej zestawionych stworzenie na jednym z Uniwersytetów polskich katedry historji i kultury bizantyńskiej wydaje się niezmiernie aktualne, a to dla wprowadzenia stałych wykładów tego przedmiotu, zgrupowania potrzebnych publikacyj, wychowania młodych pracowników naukowych, pragnących się poświęcić studjom bizantyń-

(strona 6)

-skim i zorganizowania stałego udziału nauki polskiej w międzynarodowych studjach bizantyńskich, a wreszcie - w miarę możności dla powołania do życia polskich publikacyj z dziedziny historji i kultury Bizancjum. Katedra historji i kultury bizantyńskiej jest w tej chwili bardziej potrzebna, aniżeli katedra bizantynistyki filologicznej, ponieważ studjami tej ostatniej dziedziny zajęli się od dziesiątków lat polscy filologowie klasyczni, jak prof. L. Sternbach, prof. J. Sajdak, prof. T. Sinko, dr. Turyn, co ułatwiła im ta okoliczność, że filologja klasyczna i bizantyńska posiadają wspólny teren pracy i każdy filolog klasyczny musi być obeznany z bizantyńskimi rękopisami, leksykonami, scholjami itp. Między historją starożytną a historją bizantyńską nie zachodzi ten ścisły stosunek łączności i dlatego historyczne i archeologiczne studja bizantyńskie muszą być wyodrębnione, tembardziej [sic!], że przy niewielkiej ilości katedr historji starożytnej i archeologji w Polsce, niemożliwa jest specyfikacja jednej z nich do studjów bizantyńskich, jak to szeroko praktykują uniwersytety niemieckie.

Rozważając tę sprawę, trzeba podnieść wagę studjów historji i kultury bizantyńskiej dla nauki polskiej, a to tem większą, że dotąd leżały one odłogiem. Ustanowienie katedry umożliwiłoby skierowanie szeregu badaczy najmłodszych do prac nad stosunkami między Bizancjum, a średniowieczną Polską w dziedzinie politycznej, gospodarczej i kulturalnej. Jeszcze większe znaczenie miałoby ustalenie rozmiarów pośrednich wpływów chrześcijaństwa greckiego na materjalną i duchową kulturę Polski. Wpływy te szły przez Ruś, pozostającą w zasięgu kultury bizantyńskiej, mogły też dochodzić do Polski na innych drogach pośrednich, np. za pośrednictwem Węgier, Czech, a nawet Niemiec i Włoch oraz kościoła rzymsko-katolickiego. Dopiero szerokie uwzględnienie studjów bizantyńskich pozwoli na dokładne określenie miejsca Polski w polityce i cywilizacji średniowiecznej.

Wreszcie należy tu podnieść jeden nader doniosły moment, a mianowicie znaczenie dla dziejów Polski zagadnień wypływających ze stosunków kościelnych między Wschodem a Zachodem. Już w XIV wieku należą 
(strona 7)

one do najważniejszych zagadnień państwa polskiego. Aktualność tych zagadnień niezmniejszona w dobie obecnej, wymaga koniecznie pogłębienia w Polsce znawstwa chrześcijaństwa greckiego, jego roli w historji powszechnej i jego stosunków z Zachodem dla zrównania się w tej dziedzinie co najmniej z Włochami, które mają - jak podnieśliśmy wyżej - obok katedr historji i filologji bizantyńskiej i obok szeregu ośrodków naukowych, kościelnych i świeckich, aż dwa wydawnictwa popularno-naukowego [sic!], poświęcone tej dziedzinie: "Bessarione" i "Oriente e Roma".

Wyrażamy przy tym przeświadczenie, że pośród uniwersytetów polskich Uniwersytet Jana Kazimierza we Lwowie szczególnie wchodzi w rachubę przy kreowaniu katedry historji i kultury bizantyńskiej w Polsce. Lwów leży na terenie, który w wiekach XII i XIII (w dobie istnienia państwa halickiego) stanowił najściślejszy teren wpływów politycznych, kulturalnych i gospodarczych Bizancjum. Wystarczy podnieść fakt dłuższego pobytu Andronika Komnena, późniejszego cesarza Andronika I, w Haliczu na dworze książęcym oraz fakt, że arcybiskupstwo halickie było kościelną prowincją patrjarchatu konstantynopolskiego. W XIV i XV wieku Lwów, już jako jedno z wielkich miast Polski, pozostawał $\mathrm{w}$ ścisłym kontakcie politycznym i gospodarczym $\mathrm{z}$ upadającym cesarstwem bizantyńskiem, w którego problemach miasto nasze było bezpośrednio zainteresowane, ponieważ nawet udzielało pożyczek pieniężnych cesarzom bizantyńskim. Wreszcie w następnych wiekach stosunki handlowe Lwowa $\mathrm{z}$ cesarstwem ottomańskiem $\mathrm{i}$ istnienie w mieście ruchliwej kolonji greckiej przyczyniły się do utrzymania kontaktu miasta z chrześcijaństwem greckiem. Względy te przemawiają za stworzeniem we Lwowie ośrodka studjów bizantyńskich.

Jeśliby jeden z następnych kongresów Międzynarodowych studjów bizantyńskich mógł odbyć się w Polsce, to właśnie musiałby obrać Lwów na miejsce swych obrad, a obowiązek przygotowania kongresu spadłby na uniwersytet lwowski. Wstępny warunek doprowadzenia do zrealizowania tego postulatu, którego doniosłości dla państwowej propagandy polskiej nie potrzeba uzasadniać, stanowiłoby stworzenie katedry historji i kultury bizan-

$$
\text { (strona 8) }
$$

-tyńskiej na uniwersytecie lwowskim.

Przemawia zatem wreszcie fakt niewątpliwego zainteresowania dla takiej katedry w kołach ukraińskich ze względu na związki dziejowe Bizancjum z Rusią. Stworzenie polskiej katedry bizantynologicznej we Lwowie należy uznać za jeden z kroków, które mogłyby zwiększyć oddziaływanie polskiej wyższej uczelni na młodzież ukraińską, pociągając ją do twórczej współpracy z nauką polską. Tę okoliczność należałoby takż[e] brać pod uwagę przy tworzeniu katedry.

IV. Wniosek jednak nie byłby konkretny, gdyby nie można było wymienić domniemanego kandydata, posiadającego pełne kwalifikacje do zajęcia katedry.

Takim kandydatem jest dr. Kazimierz Zakrzewski. Urodzony w roku 1900, habilitowany w r. 1927 jako docent historji starożytnej z uwzględnieniem dziejów wczesnego Bizancjum. Dr. Zakrzewski specjalizuje się od dłuższego czasu w zakresie studjów upadku świata starożytnego oraz w dziejach Bizancjum, o czem świadczą jego prace. I tak najściślej wchodzą w zakres historji bizantyńskiej prace: "Rządzy i opozycja za Arkadjusza" (Kraków 1927)91, "Un homme détat du Bas-Empire - Anthemius" (Eos 1928)92 "Le Parti Théodosien et son antithèse" (Lwów 1931 - po części przedruk

\footnotetext{
91 Zakrzewski 1927.

92 Zakrzewski 1928.
} 
francuski poprzednio wymienionych $)^{93}$, "Cezura między starożytnością a średniowieczem w świetle historji bizantyńskiej" (Warszawa 1930, V Zjazd historyków polskich) ${ }^{94}$ oraz "La cité chretiènne" (Warszawa 1933, VII kongres międzynarodowy nauk historycznych $)^{95}$, a ponadto w ścisłem związku z historją bizantyńską pozostają prace nad dziejami Italji w V wieku po Chr.: "Ostatnie lata Stilichona” (Lwów 1925, Kwartalnik historyczny) ${ }^{96}$ i "Rewolucja Odoakra” (Kraków 1933)97 oraz prace nad rozwojem wczesnego chrześcijaństwa, jak “U źródeł pobytu św. Piotra w Rzymie” (przyjęte do druku przez "Kwartalnik historyczny") 98 i "Upadek świata starożytnego" (przyjęte do druku przez "Przegląd historyczny") 99 .

Doc. Dr. Kazimierz Zakrzewski do studjów bizantyńskich przygotowywał się w r. 1925/26 w paryskiej "École pratique des Hautes Études", gdzie odbył seminarium prof. Georges[a] ${ }^{100}$ Millet[a], wybitnego badacza sztuki

(strona 9)

i kultury bizantyńskiej. Studja z zakresu kultury materjalnej pogłębił ponadto w ostatnim okresie, pracując w Zakładzie archeologji klasycznej Uniwersytetu Jana Kazimierza jako asystent-woluntarjusz. Panując nad przedmiotem i będąc badaczem zdolnym i pracowitym, Dr. K Zakrzewski szczególnie nadaje się do spełnienia tych zadań, jakie związane są z koncepcją stworzenia katedry historji i kultury bizantyńskiej.

(Edmund Bulanda)

\section{ATTEMPTS AT ESTABLISHING THE CHAIR OF HISTORY OF BYZANTIUM AT THE JAN KAZIMIERZ UNIVERSITY IN LWÓW. A CONTRIBUTION TO THE HISTORY OF BYZANTINE STUDIES IN POLAND}

\section{Summary}

This text discusses the attempts to create a chair of history of Byzantium at the Jan Kazimierz University in Lwów (today Lviv in Ukraine), in late 1933. After the end of the First World War, no chairs of Byzantine history existed at the universities in Poland. However, when Kazimierz Zakrzewski, a young scholar and expert on the history of late antiquity and Byzantium, came to Lwów, the idea to establish such a chair at the local university was conceived. Professor Edmund Bulanda drafted a special paper in which he justified the need to create a chair of Byzantine history at the Jan Kazimierz University in Lwów. The Council of the Faculty of the Humanities decided to apply to the Ministry of Religious Affairs and Public Education, with a request to have such a department created. Unfortunately, central authorities responded in the negative. Two years later, however, a chair

\footnotetext{
93 Zakrzewski 1931.

${ }_{94}$ Zakrzewski 1930.

${ }_{95}$ Poprawny zapis tytułu powinien brzmieć: La Cité Chrétienne (zob. Zakrzewski 1933b).

${ }_{96}$ Zakrzewski 1925 b.

97 Zakrzewski 1933a.

98 Zakrzewski 1934.

99 Zakrzewski 1933-1934.

100 Błędnie podane zostało tu imię uczonego, Millet miał w rzeczywistości na imię Gabriel (zob.
} wyżej, przyp. 17). 
of Byzantine history was created at the University in Warsaw and it was assumed by the very same Kazimierz Zakrzewski. In Lwów (from 1945 officially Lviv) itself, the chair of Byzantine studies was created at the beginning of the $21^{\text {st }}$ century, in the realities of the new Ukrainian state.

\section{Bibliografia}

Bieńkowski W. 1986, Ptaśnik Jan (1876-1930), historyk, profesor UJ oraz Uniw. Lwowskiego, [w:] Polski Słownik Biograficzny, 29, Wrocław-Warszawa-Kraków-Gdańsk-Łódź, s. 303-308.

Błachowska K. 2007, Stanisław Zakrzewski (1873-1936), [w:] J. Maternicki (red.), Złota księga historiografii lwowskiej XIX i XX wieku, Rzeszów, s. 377-398.

Borkowski J. 2015, Profesor Kazimierz Zakrzewski ps. „Bakałarz”, „Bobrowski” w czasie II wojny światowej, [w:] M. Dąbrowska (red.), Kazimierz Zakrzewski. Historia i polityka, Warszawa-Łódź, s. 294-308.

Ceran W. 1988, Prof. dr Halina Evert-Kappesowa i jej dorobek w badaniach nad dziejami Bizancjum, Eos, 75, s. 229-243.

Ceran W. 2002a, Acta Sanctorum, [w:] O. Jurewicz (red.), Encyklopedia kultury bizantyńskiej, Warszawa, s. 4-5.

Ceran W. 2002b, Bury John Bagnell, [w:] O. Jurewicz (red.), Encyklopedia kultury bizantyńskiej, Warszawa, s. 108.

Ceran W. 2002c, Byzantinisch-Neugriechische Jahrbücher, [w:] O. Jurewicz (red.), Encyklopedia kultury bizantyńskiej, Warszawa, s. 109.

Ceran W. 2002d, Byzantinische Zeitschrift, [w:] O. Jurewicz (red.), Encyklopedia kultury bizantyńskiej, Warszawa, s. 110.

Ceran W. 2002e, Byzantion, O. Jurewicz (red.), Encyklopedia kultury bizantyńskiej, Warszawa, s. 110

Ceran W. 2002f, Diehl Charles, [w:] O. Jurewicz (red.), Encyklopedia kultury bizantyńskiej, Warszawa, s. $142-143$.

Ceran W. 2002g, Grégoire Henri, [w:] O. Jurewicz (red.), Encyklopedia kultury bizantyńskiej, Warszawa, s. 189.

Ceran W. 2002h, Iorga Nicolae, [w:] O. Jurewicz (red.), Encyklopedia kultury bizantyńskiej, Warszawa, s. 220.

Ceran W. 2002i, Kondakow Nikodim Pawłowicz, [w:] O. Jurewicz (red.), Encyklopedia kultury bizantyńskiej, Warszawa, s. 268.

Ceran W. 2002j, Schlumberger Gustave, [w:] O. Jurewicz (red.), Encyklopedia kultury bizantyńskiej, Warszawa, s. 429-430.

Ceran W. 2002k, Uspienski Fiodor Iwanowicz, [w:] O. Jurewicz (red.), Encyklopedia kultury bizantyńskiej, Warszawa, s. 488.

Ceran W. 2002m, Wasilewski Wasilij Grigoriewicz, [w:] O. Jurewicz (red.), Encyklopedia kultury bizantyńskiej, Warszawa, s. 490-491.

Ceran W. 2002n, Wizantijskij Wriemiennik, [w:] O. Jurewicz (red.), Encyklopedia kultury bizantyńskiej, Warszawa, s. 494.

Ceran W. 2005, Początki i etapy rozwoju bizantynologii polskiej, Poznań.

Croce G.M. 1990, La badia greca di Grottaferrata e la rivista «Roma e l'Oriente». Cattolicesimo e ortodossia fra unionismo ed ecumenismo (1799-1923), Città del Vaticano.

Dąbrowska M. (red.) 2012-2014, Oskar Halecki i jego wizja Europy, 1-3, Warszawa-Łódź. 
Dąbrowska M. (red.) 2015, Kazimierz Zakrzewski. Historia i polityka, Warszawa-Łódź.

Finkel L. i Starzyński S. 1894, Historya Uniwersytetu Lwowskiego, 1-2, Lwów.

Halecki O. 1945, Kazimierz Zakrzewski, [w:] A. Ordęga i T. Terlecki (red.), Straty kultury polskiej 1939-1944, 1, Glasgow, s. 312-314.

Jolivet-Lévy C. 2020, Gabriel Millet (1867-1953) [online]. Princeton University [dostęp: 2020-01-12]. Dostępny w Internecie: <http://web.archive.org/web/20160805113244/https://ica.princeton. edu/millet/biography.php $>$.

Kalinowski L. 1976, Molè Wojsław Herman (1886-1973), [w:] Polski Słownik Biograficzny, 21, Wrocław, s. 618-620.

Kompa A. 2016, Historia starożytna na Uniwersytecie Łódzkim - przeszłość, specyfika, perspektywy, [w:] R. Kulesza (red.), Historia starożytna na polskich uniwersytetach - wczoraj, dziś, jutro, Warszawa, s. 155-198.

Korus K. 2004-2005, Sternbach Leon Samuel (1864-1940), [w:] Polski Słownik Biograficzny, 43, Wrocław, s. 473-475.

Kotłowska A. 2013, Karl Krumbacher (1856-1909), [w:] J. Strzelczyk (red.), Mediewiści II, Poznań, s. 61-67.

Kozłowski M. 2015, Kazimierz Zakrzewski na tle dyskusji o upadku cesarstwa rzymskiego w polskiej historiografii okresu międzywojennego, [w:] M. Dąbrowska (red.), Kazimierz Zakrzewski. Historia i polityka, Warszawa-Łódź, s. 46-63.

Krawczuk A. 2014, Taszyćkyj (Taszycki) Witold, [w:] Encyclopedia. Lwiwśkyj Nacionalnyj Uniwersytet imeni Iwana Franka, 2, Lwiw, s. 501-502.

Królczyk K. 2007, Polscy badacze starożytności na Uniwersytecie Lwowskim (1873-1939) - szkic do portretu, [w:] P. Berdowski, B. Blahaczek (red.), Haec mihi in animis vestris templa. Studia Classica in Memory of Professor Lesław Morawiecki, Rzeszów, s. 23-46.

Królczyk K. 2014a, Konstantin Chilinskij (1881-1939), Mnemon. Issliedowanija i publikacji po istorii anticznogo mira 14, s. 419-442.

Królczyk K. 2014b, Konstanty Chyliński (1881-1939), [w:] J. Maternicki, P. Sierżęga i L. Zaszkilniak (red.), Złota księga historiografii lwowskiej, 2, Rzeszów, s. 345-364.

Królczyk K. 2014c, Kazimierz Zakrzewski (1900-1941), [w:] J. Maternicki, P. Sierżęga i L. Zaszkilniak (red.), Złota księga historiografii lwowskiej, 2, Rzeszów, s. 551-564.

Królczyk K. 2015, Historia starożytna na Uniwersytecie Jana Kazimierza we Lwowie w okresie międzywojennym, [w:] L. Zaszkilniak i P. Sierżęga (red.), Istorija ta istoryky u Lwiwśkomu uniwersyteti: tradiciji ta suczasnist 1661-2015, Lwiw, s. 122-132.

Królczyk K. 2016, Historia starożytna, [w:] J. Maternicki, J. Pisulińska i L. Zaszkilniak (hrsg.), Historia w Uniwersytecie Lwowskim. Badania i nauczanie (do 1939 roku), Rzeszów, s. 177-201.

Królczyk K. 2019, Der Versuch der Errichtung eines Lehrstuhls für byzantinische Geschichte an der Universität in Lemberg. Ein Beitrag zur Geschichte der Byzantinistik in Polen, [w:] S. Turlej $\mathrm{i}$ in. (red.), Byzantina et Slavica. Studies in Honour of Professor Maciej Salamon, Krakow 2019, s. 227-238.

Kryvenko M. i Fayda O. 2013, Ukrainische Spuren von Karls Krumbachers Bibliothek [online]. Propylaeum-DOK - Digital Repository Classical Studies [dostęp: 2020-01-12]. Dostępny w Internecie: <http://archiv.ub.uni-heidelberg.de/propylaeumdok/volltexte/2013/1730>.

Lewandowski I. 2009, Per aspera ad astra. Z dymnej chaty galicyjskiej do najwyższych godności akademickich, czyli Jana Sajdaka życie i dzieło (1882-1967), [w:] J. Sajdak, Pod urokiem literatury patrystycznej i bizantyńskiej, Poznań, s. 9-40. 
Lyljo L. 2011, Wizantolohiji Kafedra, [w:] Encyclopedia. Lwiwśkyj Nacionalnyj Uniwersytet imeni Iwana Franka, 1, Lwiw, s. 287.

Ławrećkyj R.W. 2000, Istoryczna oswita ta nauka u Lwiwśkomu Uniwersyteti w 1918-1939 rokach, Lwiw (maszynopis dysertacji doktorskiej, dostępny w Bibliotece Uniwersyteckiej we Lwowie).

Manteuffel J. 1949, Pierre Jouguet (1869-1949), Rocznik Towarzystwa Naukowego Warszawskiego, 42, s. $174-181$.

Mrozewicz L. 2011, Badania nad dziejami Grecji i Rzymu w Poznaniu, [w:] L. Mrozewicz i K. Balbuza (red.), Świat starożytny, jego polscy badacze i kult panującego, Poznań, s. 15-31.

Oswińskyj Ju. 2011, Istoriji Serednich Wikiw i Wizantynistyky Kafedra, [w:] Encyclopedia. Lwiwśkyj Nacionalnyj Uniwersytet imeni Iwana Franka, 1, Lwiw, s. 565.

Pawlak M.N. 2015, Kazimierz Zakrzewski - badacz antyku, [w:] M. Dąbrowska (red.), Kazimierz Zakrzewski. Historia i polityka, Warszawa-Łódź, s. 34-45.

Pellisson M. 2020, Rambaud [online]. Institut Français de l'Éducation [dostęp: 2020-01-12]. Dostępny w Internecie: <http://www.inrp.fr/edition-electronique/lodel/dictionnaire-ferdinand-buisson/document.php?id=3489>.

Pisulińska J. 2007, Konstanty Chyliński - profesor historii starożytnej na Uniwersytecie Jana Kazimierza we Lwowie (1921-1939), [w:] M. Przeniosło, L. Michalska-Bracha (red.), Znani i nieznani międzywojennego Lwowa. Studia i materiały, Kielce, s. 25-34.

Plezia M. 1991, Aleksander Turyn 1900-1981, [w:] I. Bieżuńska-Małowist (red.), W kręgu wielkich humanistów. Kultura antyczna w Uniwersytecie Warszawskim po I Wojnie Światowej, Warszawa, s. 75-83.

Prostko-Prostyński J. 2015, Kazimierz Zakrzewski jako badacz późnego antyku i wczesnego Bizancjum, [w:] M. Dąbrowska (red.), Kazimierz Zakrzewski. Historia i polityka, Warszawa-Łódź, s. 64-78.

Redzik A. (red.) 2017, Academia militans. Uniwersytet Jana Kazimierza we Lwowie, wyd. 2, Kraków.

Ruland C. 1876, Bolland, Jean, [w:] Allgemeine Deutsche Biographie, 3, Leipzig, s. 109.

Rutkowski T.P. 2015, Kazimierz Zakrzewski na Uniwersytecie Warszawskim, [w:] M. Dąbrowska (red.), Kazimierz Zakrzewski. Historia i polityka, Warszawa-Łódź, s.120-130.

Salamon M. 2015, Kazimierza Zakrzewskiego wizja średniowiecznego Bizancjum, [w:] M. Dąbrowska (red.), Kazimierz Zakrzewski. Historia i polityka, Warszawa-Łódź, s. 79-104.

Schneider H. 2012, Rostovtzeff, Michael Iwanowitsch, [w:] P. Kuhlmann i H. Schneider (hrsg.), Geschichte der Altertumswissenschaften. Biographisches Lexikon (= Der Neue Pauly. Supplemente, Band 6), Stuttgart-Weimar, kol. 1083-1089.

Sjuzmow M.J. 1973, Uspenskij Konstantin Nikołajewicz [1874-14(27).V.1917], [w:] Sowieckaja Istoriczieskaja Encikłopedija, 14, s. 881-882.

Soroczan S.B. i Wojtowycz L. W. (red.) 2011, Istorija Wizantii. Wstup do wizantynistyky, Lwiw.

Sprawski S. 2018, Ludwika Piotrowicza badania nad historią starożytną, [w:] T. Gąsowski i J. Smołucha (red.), Krakowskie środowisko historyczne XV-XX w. Ludzie - idee - dzieła, Kraków, s. $225-248$.

Sprawozdania z działalności Uniwersytetu Józefa Piłsudskiego w Warszawie za rok akademicki 193435 i za rok akademicki 1935-36 złożył rektor Uniwersytetu tychże lat dr Stefan Pieńkowski, Warszawa 1936.

Studi Bizantini 2020 [online]. Catalogo Italiano dei Periodici [dostęp: 2020-01-12]. Dostępny w Internecie: <https://acnpsearch.unibo.it/journal/40370>.

Sytnyk O. 2012, Archeolohiczna nauka u Lwowi. Persza połowyna XX stolittja, Lwiw-Rzesziw. 
Śreniowska K. 1994, Modelski Teofil Emil, [w:] M. Prosińska-Jackl (red), Słownik historyków polskich, Warszawa, s. 358.

Turasiewicz R. 1996-1997, Sinko Tadeusz (1877-1966), [w:] Polski Słownik Biograficzny, 27, Wrocław, s. 548-552.

Uniwersytet Poznański. Spis wykładów na 1, 2, 3 trymestr roku akademickiego 1928/29, Poznań 1928.

Witkowski W. 2000, Jan Janów, [w:] J. Michalik (red.), Złota księga Wydziału Filologicznego, Kraków, s. $378-383$

Zakrzewski K. 1925a, Samorząd miast Achai rzymskiej. Arkadja-Messenia-Lakonia, Lwów.

Zakrzewski K. 1925b, Ostatnie lata Stilichona, Kwartalnik Historyczny, 39, s. 445-514.

Zakrzewski K. 1927, Rządy i opozycja za cesarza Arkadjusza, Kraków.

Zakrzewski K. 1928, Un homme d’etat du Bas-Empire: Anthémius, Eos, 31, s. 417-438.

Zakrzewski K. 1930, Cezura miedzy starożytnością a średniowieczem w świetle historji bizantyńskiej, [w:] Pamiętnik V Powszechnego Zjazdu Historyków Polskich w Warszawie 28 listopada do 4 grudnia 1930 r., 1: Referaty, Lwów, s. 72-104.

Zakrzewski K. 1931, Le parti Théodosien et son anti-thèse, Leopoli.

Zakrzewski K. 1933a, Rewolucja Odoakra, Kraków.

Zakrzewski K. 1933b, La Cité Chrétienne, [w:] La Pologne au VII-e Congrès international des sciences historiques, 1, Varsovie, s. 391-408.

Zakrzewski K. 1933-1934, Upadek świata starożytnego, Przegląd Historyczny, 31, s. 185-211.

Zakrzewski K. 1934, U źródeł pobytu św. Piotra w Rzymie, Kwartalnik Historyczny, 48, s. 1-46.

Zakrzewski K. 1935, Upadek Cesarstwa Rzymskiego i kultury antycznej, [w:] Pamiętnik VI Powszechnego Zjazdu Historyków Polskich w Wilnie 17-20 września 1935 r., 1: Referaty, Lwów, s. $459-473$.

Ziomecki J. 1998, Edmund Bulanda (1882-1951), [w:] J. Śliwa (red.), Archeologia śródziemnomorska w Uniwersytecie Jagiellońskim 1897-1997. Materiały sympozjum naukowego Kraków, 21-23 października 1997, Kraków, s. 35-39.

Żuławska J. 1955, Stanisław Witkowski 1866-1950, Meander, 10, z. 5, s. 273-276. 